Gerión. Revista de Historia Antigua

ISSN: 0213-0181

\title{
Elementos clásicos en el pensamiento político de Juan Ginés de Sepúlveda
}

\author{
Salvador Mas Torres ${ }^{1}$
}

Recibido: 19 de febrero de 2019 / Aceptado: 19 de mayo de 2019

Resumen. En el contexto del pensamiento renacentista, las referencias al Mundo Clásico se convirtieron en modelos conceptuales al servicio de la construcción de la experiencia histórica y política y de la propia identidad cultural. En este marco general situaré la función que los elementos clásicos desempeñan en el pensamiento de Juan Ginés de Sepúlveda. Me centraré, por una parte, en la desconfianza con la que los teólogos dominicos miran el latín clasicista de Sepúlveda, que se conjuga mal con la univocidad de la lengua y la terminología acuñada a lo largo de la tradición filosófico-escolástica. Por otra, en la utilización que realiza Sepúlveda de las explicaciones aristotélicas sobre la esclavitud natural; argumentaré que la tesis de la inferioridad natural de los indios no es del todo relevante y que Sepúlveda no recurre a Aristóteles para justificar las conductas brutales de los encomenderos, sino para negar a los indios la condición de sujetos políticos.

Palabras clave: traducción; Nuevo Mundo; esclavitud natural.

\section{[en] Classical Elements in the Political Thought of Juan Ginés de Sepúlveda}

\begin{abstract}
In the context of Renaissance thought, references to the Classical World became conceptual models to construct not only historical and political experience, but also cultural identity. In this general context, I will analyse the role that classical elements play in the political thought of Juan Ginés de Sepúlveda. I will focus, on the one hand, on the distrust with which the Dominican theologians approached the classicism of Sepulveda's Latin, which does not mesh well with the unicity of the language and the terminology coined across the philosophical-ecclesiastical tradition. On the other hand, I will focus on the use that Sepúlveda makes of the Aristotelian concept of natural slavery; the notion of the Indians' natural inferiority is irrelevant, and Sepúlveda does not use Aristotle to justify the Conquistadors' brutal treatment of the Indians, but to deny the Indians their condition as political subjects.
\end{abstract}

Keywords: Translation; New World; Natural Slavery.

Sumario. 1. Introducción. 2. Sobre el arte de traducir y sus implicaciones. 3. Los peligros de los studia humanitatis. 4. Pacifismo y deseo de gloria. 5. Derecho natural y esclavitud. 6. A la sombra del miedo florece la virtud. 7. Hacer el mal para alcanzar el bien. 8. Otium cum dignitate. 9. Referencias bibliográficas.

Cómo citar: Mas Torres, S. (2019): Elementos clásicos en el pensamiento político de Juan Ginés de Sepúlveda, en Gerión 37/2, 425-448.

1 Universidad Nacional de Educación a Distancia.

E-mail: smas@fsof.uned.es 


\section{Introducción}

Para conjurar la extrañeza que provocó la radical novedad del Nuevo Mundo y que dejó a los europeos sumidos en la perplejidad fue habitual recurrir a la analogía, positiva o negativa; en los cronistas son frecuentes ambas formas de ver las cosas: "esto es como" -o sea, "esto es normal, tradicional, racional"-y "esto es diferente de" -o sea, "esto es anormal, irracional" y, por tanto, "intranquilizante"-. Afinidad y singularidad, por decirlo con Antonello Gerbi. ${ }^{2}$

Y entre la afinidad y la singularidad se mueven muchas de las analogías trazadas para intentar comprender el Nuevo Mundo; por eso, en las crónicas y relatos de Indias hay continuidad entre historia, ficción y política, en ocasiones a través de la mediación de la Antigüedad. ${ }^{3}$ No escasean, por ejemplo, las comparaciones de los conquistadores con héroes mitológicos como Ulises, Jasón o Hércules, ${ }^{4}$ o históricos como Julio César, el cual, escribe Fernández de Oviedo, fue superado por Hernán Cortes. ${ }^{5}$ Son también frecuentes las asimilaciones más o menos forzadas de los indios con grupos míticos. ${ }^{6}$ Sin embargo, a partir de determinado momento las referencias al Mundo Clásico dejan de ser solo un conjunto de analogías, positivas o negativas, y se convierten en modelos conceptuales al servicio de la construcción de la experiencia histórica y política, ${ }^{7}$ modelos que implican sofisticadas visiones en las que la Antigüedad se pone al servicio de la construcción de la propia identidad cultural, aunque solo sea porque el recurso a modelos antiguos supone y exige tomar distancia frente a la propia cultura heredada. En este contexto general desearía situar la función que los elementos clásicos desempeñan en el pensamiento de Juan Ginés de Sepúlveda.

Juan de Sepúlveda nació en Pozoblanco en 1490 y murió en esta misma localidad cordobesa en el 1573. De orígenes humildes, pudo sin embargo estudiar en la Universidad de Alcalá, donde obtuvo el título de bachiller en Artes y Teología y alcanzó un excelente conocimiento de las lenguas clásicas. Posteriormente, marchó a Italia para completar su formación, donde fue colegial del Real Colegio de España en Bolonia y entró en contacto con círculos humanistas. En el 1535, nombrado cronista y capellán de Carlos I, regresó a España y más adelante fue preceptor del futuro Felipe II. Un hombre, pues, muy de su época, con una excelente formación y con una decidida vocación práctica y política. Nos encontramos, pues, ante un "humanista", pero estos individuos, los humanistas, no son -o no solo, o no necesariamente- benefactores que, armados con el espíritu y la cultura clásicas, combaten el fanatismo y la ignorancia medieval, individuos de criterio libre que luchan por expresar la verdad por encima de presiones y banderías; los humanistas poseen una serie de conocimientos y saberes y pretenden vivir de ellos: ofrecen un servicio y solicitan contrapartidas, ${ }^{8}$ especialmente si son de origen humilde, como

\footnotetext{
Gerbi 1978, 18-20.

Fabregat Barrios 2003.

Reynolds 1962, 259.

Historia general, libro 33, cap. 20, 97.

Alexandre Coello de la Rosa ha estudiado el caso de las amazonas (2012: "Las hijas de Marte en el Nuevo Mundo", cap. 4).

7 Sabine MacCormack lo ha señalado a propósito del caso concreto del Perú: "The emergence of the land of Peru, understood both geographically and conceptually, reveals the classical and Roman themes that pervade our texts to have been more than instruments of description and analysis. Rather, they also became constituents of collective consciousness and identity" (2009, xv).

$8 \quad$ Ynduráin 1994, 122; Rus Rufino 2010, vii.
} 
era el caso de Sepúlveda. En Italia, donde, decía, completó su formación intelectual y vivió largo tiempo, ${ }^{9}$ se cotizaba el dominio del latín y del griego. No sorprende que la lectura "humanista" de los clásicos griegos y romanos acostumbre a ser profesional y utilitaria. ${ }^{10}$

"Los humanistas tratan de hacer imprescindibles sus enseñanzas y las habilidades que dominan, y tal y como ellos las dominan: se proponen sustituir como consejeros áulicos y como voceros a los juristas y los teólogos". ${ }^{11}$ Los humanistas, en efecto, quieren intervenir en política. Estamos ante un tema tradicional, el de la vinculación entre filosofía y política, y, a este respecto, si acaso con la excepción de los epicúreos, en la Antigüedad hay consenso acerca de la pertinencia, incluso la necesidad, de que el filósofo -si no rey-se haga presente en la vida pública al menos indirectamente, con sus consejos, con su actividad intelectual, con su ejemplo. La obra de Sepúlveda es variada y polifacética, pero en toda ella, implícita o explícitamente, anida una intencionalidad política.

Sin embargo, la "eticidad del destino", por decirlo con Hegel, ha querido que pase a la historia como el enemigo de fray Bartolomé de las Casas, como el astuto y erudito defensor del imperialismo español que con innegable pericia sabe acudir a textos aristotélicos para defender las atrocidades que los conquistadores cometieron en el Nuevo Mundo. Más adelante regresaré a esta cuestión.

\section{Sobre el arte de traducir y sus implicaciones}

Gonzalo Fernández de Oviedo (1478-1557) es el autor de uno de los documentos más fascinantes sobre el Nuevo Mundo, la Historia general y natural de las Indias; si lo menciono en estas líneas es por ser una de las principales fuentes de Sepúlveda en asuntos americanos, razón no única, aunque sí suficiente para que las iras de Bartolomé de las Casas también se dirijan contra aquel. En la Apología hay un capítulo, el 58, titulado: "Motivos por los que Oviedo difamó a los indios": "Dios, por sus crímenes, le había cegado para no conocer la buena disposición de los indios". ${ }^{12}$ Pero la incomprensión de Fernández de Oviedo de la verdadera naturaleza de los indios también obedece a su desconocimiento del latín, que le impidió estudiar más y tener una concepción más acertada de los indios:

Si Oviedo hubiese puesto tanto cuidado en todo esto como lo puso en dedicarse completamente durante toda su vida a cosas profanas para dar la impresión de persona docta (él que jamás aprendió latín), sin duda hubiera moderado todo el mal que falsamente dijo. ${ }^{13}$

9 Muñoz Machado (2012) ofrece una buena biografía de Sepúlveda; sobre el periodo italiano en concreto, caps. 3 ("Incorporación a la cultura del Renacimiento italiano: emergencia del humanista") y 4 ("Tiempos romanos"). Sobre las fechas de concepción, redacción y, en su caso, publicación de las obras de Sepúlveda, remito a las "Introducciones" y "Estudios preliminares" citados en la bibliografía.

10 Debe reconocerse que, al menos desde este punto de vista, la actividad de Sepúlveda se vio coronada por el éxito: el cultivo de las letras le permitió reunir un importante patrimonio. "Como a Lope el amor, a nuestro cronista le domina el afán por acrecentar su hacienda". Ángel Losada, a quien cito, ofrece la lista de los beneficios eclesiásticos que Sepúlveda obtuvo a lo largo de su vida $(1973,154)$.

11 Ynduráin 1994, 122.

12 Apología I, cap. 16.

13 Apología I, cap. 16. 
En efecto, "muchas y en muchas cosas Oviedo alega libros y autoridades que él nunca vio ni entendió, como él no entienda ni sepa latín". ${ }^{14}$ Los estudiosos modernos coinciden en señalar que es muy probable que Fernández de Oviedo tuviera al menos un conocimiento mediano e instrumental del latín. ${ }^{15} \mathrm{Y}$ si hemos de hacer caso a Ángel Losada, que conoce bien el latín de Las Casas en su calidad de traductor al castellano de la Apología, tampoco el dominico era un excepcional conocedor de la lengua de los romanos: "Las Casas, que no brillaba precisamente por latinista, no era el más indicado para hacer un tal reproche". ${ }^{16}$

Juan Ginés de Sepúlveda, por el contrario, conocía excelentemente las lenguas clásicas: estamos ante uno de los más destacados traductores renacentistas de Aristóteles al latín. ${ }^{17}$ En el prefacio a su traducción de los Comentarios de Alejandro de Afrodisias sobre la Metafísica se asombra de que en Roma, donde se veneraba a Platón y Aristóteles "como dos seres divinos" y donde no faltaban "multitud de varones muy sabios en griego y latín", no hubiera habido nadie que se ocupara de presentar sus escritos "con un estilo apropiado al momento, a la vez que fiel". ${ }^{18}$ Él, por su parte, se ve llamado a esta tarea: se siente por entero dentro de la praxis traductora renacentista, ${ }^{19}$ se considera heredero de Argirópulo por rechazar radicalmente la traducción ad verbum. ${ }^{20}$ Aunque no escribió una monografía específica dedicada al arte de traducir, cabe espigar aquí y allá -en sus cartas, en los prólogos a sus traducciones- noticias sobre este menester. Cito a modo de ejemplo unas líneas del prefacio a su traducción de la Política de Aristóteles:

Pues no pienso que deban ser considerados traductores quienes con una fidelidad torpe traducen palabra por palabra, y tampoco quienes, poco versados en la filosofía y en la teoría aristotélicas, traducen numerosos pasajes erróneamente.

Aunque reconoce la dificultad que se le plantea al traductor para ser al mismo tiempo aristotélico y ciceroniano, entiende que es "bastante ciceroniano" al menos en la medida en que utiliza "un estilo llano y claro, en la medida en que el tema lo consiente". ${ }^{21}$

La traducción no se limita a establecer un puente cultural entre el mundo antiguo y el moderno. ${ }^{22}$ Los traductores renacentistas, y Sepúlveda no es una excepción, quieren generar una nueva latinidad que marque diferencias frente a la cultura de la

\footnotetext{
Apología III, cap. 143.

Pérez de Tudela 1959, clxvi; Turner 1971, 142-143; Avalle-Arce 1974, 13; Gerbi 1978, 286.

Losada 1970, 381.

Gil 2007, cxxvii-cxxix.

Epistolario, documento 6, 25 .

Un buen planteamiento general en Furlan 2002.

Losada 1973, 45-46.

21 Epistolario, documento 67, 172. Véase también el Prefacio a su traducción de los Parvi naturales: "En efecto, aquella antigua traducción palabra por palabra que usaban los filósofos latinos antes de Argirópulo había sometido los entendimientos a tantos errores que los expositores lo explicaban casi todo erróneamente y el resto más bien lo obtenían más por adivinación que por entenderlo" (Epistolario, documento 2, 9). O el Prefacio a la traducción de los Comentarios de Alejandro de Afrodisias sobre la Metafísica: “... pienso que no son dignos del nombre de traductores los que tanto se empeñan en traducir a los griegos con una exactitud en cierto modo tan bárbara que no toleran con buen ánimo la supresión de ninguna palabra ... Y esto les ocurre al pensar que, desentendiéndose del pensamiento, cumplen con la tarea del traductor con tal de ser fieles, con absurda precisión, hasta la partícula más elemental" (Epistolario, documento 6, 28).

22 Gualdo Rosa 1985, 177-194.
} 
Edad Media y sea instrumento de formación intelectual y moral. Además, sus traducciones no se dirigen a un público especializado de teólogos o profesores universitarios, pues ambicionan audiencias más amplias: diletantes que buscan nuevas mercancías culturales y piden (o exigen, pues pagan) les sean servidas de una forma legible y en una prosa que halague sus conocimientos del latín más clásico. ${ }^{23}$ Por eso estos traductores ofrecen textos respetuosos con el sentido del texto original, pero que, lejos de todo literalismo, atienden especialmente a las exigencias gramaticales y sintácticas de la lengua de llegada, en nuestro caso el latín, el latín de Cicerón: "la huella de Cicerón es evidente por doquier", escribe Juan Gil. ${ }^{24}$

En el literalismo hay en muchas ocasiones, ciertamente, el desconocimiento de la lengua de la que se traduce, ${ }^{25}$ pero también el convencimiento de que únicamente la traducción ad verbum permite salvar el auténtico pensamiento del autor traducido, ${ }^{26}$ mas al precio de generar textos oscuros, en ocasiones incomprensibles. Por eso Bruni quiere arrebatar a Aristóteles de las garras de los aristotélicos, porque han generado textos incomprensibles. ${ }^{27} \mathrm{La}$ cuestión que interesa en estas páginas comienza a perfilarse: ¿quién puede interpretar?

Tal es la problemática que subyace en la polémica entre Bruni y Cartagena. No es inhabitual considerar al segundo el escolástico medieval incapaz de comprender las nuevas tendencias propugnadas y puestas en práctica por Bruni. ${ }^{28} \mathrm{Y}$ Bruni, no lo olvidemos, frente a las incomprensibles versiones medievales, traduce a Aristóteles a un latín que quiere ser ciceroniano. Para Cartagena esto supone traicionar a Aristóteles, es desconocer el carácter filosófico de su obra y convertirlo en un orador como Demóstenes y Esquines,${ }^{29}$ lo mismo que los teólogos dominicos reprochan a los humanistas. En efecto, aquellos miran con desconfianza el latín clasicista de Sepúlveda, que se conjuga mal con la univocidad de la lengua y la terminología acuñada a lo largo de la tradición filosófico-escolástica: la latinitas medieval desentona de ese ciceronianismo renacentista del que también participa Sepúlveda: traducir de una manera y no de otra implica diferencias en el modo de leer y asimilar a los clásicos. ${ }^{30}$

En carta a Martín Oliván, Sepúlveda se lamenta de que algunos teólogos le reprocharan su "larga dedicación al cultivo del latín, del griego y de la elocuencia", convencidos como estaban de que "todo lo que se me otorga en el campo de los estudios filosóficos se me resta en el de los teológicos". " ${ }^{31}$ Y, en carta a Hernán Núñez Pinciano, reconoce que recurre a Aristóteles y Platón "con más frecuencia que la que parecía bien a ciertos teólogos". ${ }^{32}$ Tiene razón Anthony Pagden cuando califica a Sepúlveda de humanista y cuando afirma que, para sus adversarios dominicos, un humanista es un retórico, un literato, que no debe intervenir en cuestiones teológicas o teológico-jurídicas, solo al alcance de individuos con gran preparación. ${ }^{33}$ Justamente

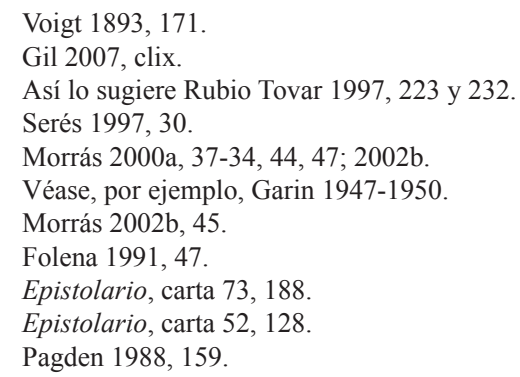


la preparación que Sepúlveda consideraba que poseía y negaba a sus rivales dominicos. ${ }^{34}$ Dicho directamente: se trata de saber si estamos ante problemas jurídicoteológicos o político-morales; si lo segundo, si cabe secularizar problemáticas antaño teológicas, es entonces pertinente recurrir al Mundo Clásico. ¿Quién puede interpretar?

En efecto, la crítica filológica, en particular aplicada a textos bíblicos y patrísticos, es peligrosa, aunque solo sea porque puede atentar contra el principio de que únicamente la autoridad pontificia está autorizada para establecer el dogma cristiano. Insisto una vez más: fijar fuentes y traducir de una u otra manera es, desde luego, una tarea filológica, pero con implicaciones que van más allá de esta bella disciplina. No basta la formación técnica filológica, porque el Mundo Antiguo está lleno de trampas y celadas, porque es peligroso acercarse a él sin poseer una sólida formación, y porque ahora, en el Renacimiento, sus productos llegan a las manos de individuos de toda índole. Ejemplificaré con algunos textos de Sepúlveda.

\section{Los peligros de los studia humanitatis}

E1 Del rito de las nupcias de Sepúlveda versa sobre el matrimonio y su dispensa; más en concreto, se dirige contra el divorcio de Enrique VIII de Catalina de Aragón. Y al hilo de esta cuestión se hacen algunas consideraciones que pueden ser pertinentes en estas páginas; es interesante, en efecto, el paralelismo que en el prefacio se traza entre clasicistas y luteranos: unos y otros pisotean las leyes divinas y eclesiásticas que defienden la santidad del vínculo matrimonial. ¿Corrompe la literatura griega? ¿Traducirla puede incitar a la corrupción? En el Sobre el destino y el libre albedrio la respuesta parece ser afirmativa; a propósito de "la abominable maquinación del hombre más infame" (o sea, Lutero), Sepúlveda escribe que el estudio de la elocuencia y las humanidades "acarreó a los alemanes esta epidemia de lo más perniciosa". Sepúlveda sabe que Lutero es un hombre cultivado, un buen conocedor de la cultura y las lenguas clásicas; su "reputación de una no mediocre elocuencia y formación" lo realzó ante la juventud alemana. ${ }^{35}$ También en el Sobre el destino menciona al helenista alemán Ulrich von Hutten, "hombre loco de atrevimiento y de los más dispuestos para alimentar partidismos":

Me refiero a quienes versados en los estudios humanísticos creen a sus ojos y a los del pueblo ignorante ser alguien ... dan rienda suelta a su hueca charlatanería, lo único que adquirieron con sus estudios. ${ }^{36}$

En la carta a Martín Pérez de Oliván del 13 de diciembre de 1547, la posición es más matizada. El inquisidor apostólico había preguntado a Sepúlveda su opinión acerca de ese pasaje en el que Catón criticó las "letras griegas":

Pues, al igual que en otro tiempo el estudio y el conocimiento de las letras griegas trajo consigo una gran degeneración de costumbres para los romanos, del mismo modo recientemente ha producido una profunda mancha religiosa para los

\footnotetext{
Véase, por ejemplo, la carta a Luis Lucena del 1 de enero de 1549 (Epistolario, carta 76).

I 1, p. 4.

I 10, p. 9.
} 
alemanes, de modo que con razón la añeja disputa parece poder renovarse con nuevos ejemplos. ${ }^{37}$

Sepúlveda considera "falsa e injusta la acusación de Catón". Al margen de que la culpa de la corrupción de Roma no la tuvieron los studia humanitatis, sino -dice Sepúlveda recuperando un tópico ya habitual, al menos desde el periodo de la crisis de la República romana- el prolongado tiempo de paz, tranquilidad y bienestar que siguió a las Guerras Púnicas, todo depende de en qué manos caiga la literatura griega. El problema no son los studia humanitatis en sí mismos, sino la catadura moral de algunos de sus cultivadores. Sepúlveda no niega que "las desgracias y la depravación de la religión de los alemanes han sido traídas por estudiosos de la elocuencia y las letras griegas", pero de aquí solo se sigue la maldad de estos estudiosos, no la deshonestidad de tales letras. ${ }^{38}$ Insisto: si el estudio del Mundo Clásico -y el dominio de sus lenguas- es condición imprescindible para la correcta conducción de la vida pública y privada, no es, ni mucho menos, condición suficiente. El caso de Lutero prueba exactamente lo contrario. La eloquentia griega no tuvo la culpa de la protesta germana, sino la falta de un Tribunal de la Inquisición, es decir, de una instancia jurídica suprema "para reprimir la audacia criminal de unos hombres violentos e ignominiosos que pretendían provocar una revolución religiosa". ${ }^{39}$ Aunque Sepúlveda no lo diga expresamente, cabe suponer que entre las tareas de tal instancia se encuentran las de decidir qué leer (y traducir) y qué no, así como quién debe hacerlo.

Debe interpretarse a Aristóteles correctamente, no como "los maestros de la impiedad luterana", los cuales "hinchados por cierta huera palabrería que alcanzaron por el estudio de la literatura griega y latina, emiten juicios necios y arrogantes sobre los más grandes varones, a los que apenas conocen". ${ }^{40}$ Los buenos conocedores de Aristóteles saben que cristianos y peripatéticos coinciden en que la honestidad es denominador común de todas las virtudes:

Así pues, quede firmemente establecido, también de acuerdo con los teólogos, que los cristianos no discrepan de los peripatéticos en los tratados morales sobre virtudes y vicios, que se determinan según la razón natural, y que unos y otros consideran erróneo, en cuanto al vivir, apartarse de la naturaleza y de la recta razón. ${ }^{41}$

Y, de hecho, afirma en carta a Gian Matteo Giberti, escribió el Demócrates "para poner de acuerdo en la enseñanza moral a los teólogos con los peripatéticos", para lo cual "fue necesario examinar cuidadosamente de un lado las Sagradas Escrituras y de otro todos los vericuetos, por así decir, de Aristóteles". ${ }^{42}$

Sepúlveda maneja fuentes clásicas y cristianas y, dependiendo de las circunstancias concretas o de las necesidades argumentativas del momento, da prioridad a unas $u$ otras: "funcionaliza" a los clásicos, porque el recurso a la Antigüedad -a cierta Antigüedad- sirve entre otras cosas para generar un cristianismo no erasmista,

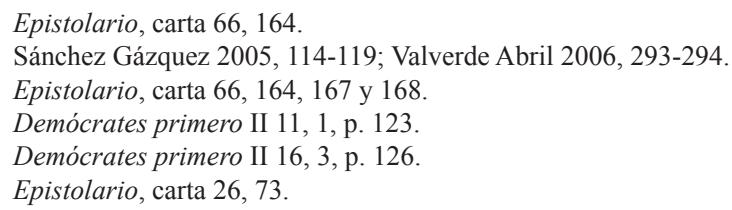


mundano y secular, o sea, permite interpretar la ley evangélica en sentido débil o incluso figurativo. No se limita a traducir a Aristóteles, sino que, dice, bebe "de estas fuentes, según mi parecer y criterio, en la medida en que parezca oportuno". En esta misma obra reconoce la inspiración de Aristóteles - "persona extraordinaria"- e insiste en que su filosofía moral y política no difiere de la cristiana: una y otra "versan sobre lo que es honesto en las costumbres y justo conforme al orden natural, que coincide con la ley eterna". ${ }^{43}$ Con Aristóteles en la mano derecha y las Escrituras en la izquierda basta con ser suficientemente hábil para concluir, en efecto, lo que en cada caso se considere más oportuno. ${ }^{44}$

\section{Pacifismo y deseo de gloria}

Sepúlveda considera que Erasmo ha cometido errores técnicos filológicos en la traducción y exégesis de algunos pasajes del Nuevo Testamento, ${ }^{45}$ y critica duramente su pacifismo evangélico. Su estrategia es clara: mostrar que no hay contradicción entre la ley natural de los filósofos y la normatividad cristiana: dado que cuanto se hace por derecho o ley natural también se hace por derecho divino, del mandato evangélico de "poner la otra mejilla" no se sigue que Cristo "abolió la ley natural según la cual a todo hombre le está permitido repeler la fuerza con la fuerza". ${ }^{46}$ Por lo demás, la ley evangélica, en toda su pureza y radicalidad, solo se verifica en las formas más ascéticas del monacato. ${ }^{47}$ En la vida cotidiana basta con observar las leyes de la naturaleza, esa normatividad natural que pusieron de manifiesto los filósofos antiguos. Sepúlveda desea disolver la tensión, agudamente percibida por los erasmistas, entre el mensaje cristiano y las exigencias de organización de la sociedad, donde parece inevitable la violencia y el deseo de gloria, y para legitimar esta "inevitabilidad", obviamente, son más útiles los filósofos clásicos y el ejemplo de los romanos que el Evangelio. ${ }^{48}$

También contra el pacifismo escribió Sepúlveda el Demócrates primero y también este texto es, entre otras cosas, una exaltada celebración de la Roma clásica como

$43 \quad$ Acerca de la monarquía I 1, p. 48.

44 Ghia 2008, 14, 66.

45 Detalles en Losada 1973, 77. Véase la carta a Erasmo de Rotterdam del 23 de octubre de 1533 (Epistolario, carta 23).

46 Demócrates segundo I 2, 1-2, 44. Véase la carta a Melchor Cano del 26 de diciembre de 1548 (Epistolario, carta 74). También, al mismo remitente, las cartas 81 y 82.

47 Losada 1973, 141-142.

48 No extraña, pues, que los erasmistas valoraran el modelo romano de manera muy diferente a Sepúlveda. Las glorias militaristas y la ferocidad del imperialismo romano repugnaban a los primeros. "César, pestilencia de todo el mundo", escribe Vives en su Pompeius fugiens. Contra el pacifismo de Erasmo y Vives escribió Sepúlveda el diálogo De appetenda gloria dialogus, qui inscribitur Gonsalus, una defensa del deseo de gloria rebosante de paralelismos entre episodios de la antigua Roma y de la España más reciente, porque la gloria militar de los primeros se prolonga en la segunda, esa misma gloria que Vives, en el libro primero de su De concordia et discordia in humano genere, considera responsable de la degeneración demoniaca que ha experimentado el género humano, degeneración en la que los romanos representan un hito esencial. En el Gonsalus, Sepúlveda celebra con tonos entre épicos y elegiacos la heroica caída de numantinos y saguntinos, Vives ve en estos pueblos víctimas de la rapacidad imperialista romana, la misma depredación que muestran los españoles en el Nuevo Mundo y que Vives considera otro decisivo hito degenerativo (De concordia et discordia, 104). Hay traducción de estas obras de Vives a cargo de Lorenzo Riber 1947, las citas en el vol. I, 589 y en el II, 98-99 y 104. Véase Lupher 2006, 589. 
modelo para la Europa contemporánea. ${ }^{49}$ Detengámonos por un momento en el problema de la relación entre vida contemplativa y vida activa, tal y como Sepúlveda lo plantea en esta obra siguiendo libremente la distinción aristotélica entre virtudes morales e intelectuales. ${ }^{50}$ La primera es una vida entregada a la búsqueda de la felicidad eterna -o de la verdad eterna, por decirlo con San Agustín-; la segunda mira al trabajo y a las obligaciones civiles, entre las que se encuentra servir en la guerra. Ambas formas de vida son desiguales en importancia. Sepúlveda concede que la contemplativa es superior: nada puede haber más importante que entregarse a buscar esa sabiduría que proviene de Dios y a él acerca. Lo cual no supone condenar la vida activa: de la superioridad de la vida contemplativa no se desprende la ilegitimidad de la activa. Por lo demás, como escribe en carta a Antonio Córdoba citando a Aristóteles, excepto la divinidad "nadie puede vivir perpetuamente en la contemplación". ${ }^{51}$

Sepúlveda ha estudiado y vivido en Bolonia y es muy probable que experimentara la influencia del aristotelismo averroísta de Padua: si no "doble verdad", sí al menos la necesidad de distinguir ámbitos, de diferenciar. Lo cual, a su vez, puede llevar a autonomizar el discurso político-moral frente al teológico. ${ }^{52} \mathrm{Y}$ en la raíz de tal autonomización puede detectarse un maquiavelismo más o menos confeso. ${ }^{53}$ Aunque el florentino, a diferencia de Sepúlveda, no sentía la necesidad de argumentar la compatibilidad entre las virtudes y valores paganos y la ética cristiana, uno y otro tenían protectores comunes, provenían de ambientes culturales próximos y defendían una visión "realista" de la política. ${ }^{54}$

Maquiavelo lamenta que el cristianismo haya roto la vinculación que la Antigüedad romana había establecido entre la religión y las virtudes civiles. Tesis esta, para Sepúlveda, fácil de refutar: basta con contraponer a los exempla romanos de Maquiavelo la multitud de exempla ibérico-cristianos que desfilan, por ejemplo, a lo largo de las páginas del Demócrates primero. En general, estamos ante el debatido problema de la guerra justa que Sepúlveda, en este texto, solventa recurriendo a las leyes de la naturaleza (entendidas aristotélicamente) y buscando luego, retóricamente, apoyo en la ideas agustinianas de que las guerras son queridas y permitidas por Dios por sus funciones purificadoras y santificadoras ${ }^{55}$ así como de que la pertenencia a la comunidad cristiana es criterio (el único criterio) para establecer una igualdad de derechos universal. ${ }^{56}$ Más adelante regresaré a estas

\footnotetext{
Lupher 2006, 111.

I, 10-17.5.

Epistolario, carta 102, 299.

52 Bartolomé de las Casas era muy consciente de este peligro. De acuerdo con el fraile, Aristóteles considera que "es licito el capturar o cazar a los bárbaros de esta clase [los bárbaros en sentido estricto] para atraerlos a un recto modo de vida". Dado que el Estagirita desconocía "la verdad y la caridad cristianas", su análisis muestra aquí su límite infranqueable: “¡Adiós, Aristóteles! De Cristo, que es la eterna verdad, tenemos el mando: ‘Amarás a tu prójimo como a ti mismo"” (Ap. capt. 3, 101). Comenta sobre este texto Francisco Fernández Buey: "El exabrupto es seguramente reflejo de la pasión moral del cristiano consecuente que sabe que está combatiendo una doble batalla: contra el aristotelismo y contra una parte de los suyos. Una doble batalla que lleva a Las Casas a poner el dedo en la verdadera llaga en esta discusión: el uso ideológico, históricamente determinado de la filosofía aristotélica, y en particular de la concepción esclavista de Aristóteles, para justificar un nuevo tipo de servidumbre en circunstancias completamente insólitas para todo aristotelismo" (1995, 74).

53 Maravall 1984, 39; Coroleu 1992; y, especialmente, Castilla Urbano 2008.

54 Muñoz Machado 2012, 280.

55 Brière 1944, 37.
}

56 Pehlan 1974. 
cuestiones. De momento, solo señalar que Maquiavelo y Sepúlveda apuntan a flexibilizar el concepto de guerra justa. Tal flexibilización tiene dos puntos de apoyos teóricos: la unidad de las virtudes y una relectura de la concepción tomista, de raíz ciceroniana, del derecho natural.

Para defender la legitimidad de la guerra y, por tanto, de la profesión militar y sus glorias, Sepúlveda argumenta que no puede suprimirse una virtud sin suprimirlas todas y supone que a este respecto hay consenso tanto entre los filósofos como entre los cristianos. Por tanto, si los cristianos no pueden ejercer las virtudes marciales, o sea, la fortaleza y la magnanimidad, "es preciso confesar que las demás virtudes les son negadas". ${ }^{57}$ Leopoldo, próximo al luteranismo y que, por tanto, asume el papel de objetor, rechaza con energía la estrategia argumentativa de Demócrates a través del cual Sepúlveda expone sus tesis:

Así pues, no apruebo ese procedimiento de debatir, de modo que, cuando se trata de leyes y normas cristianas y corresponde solventar la disputa con testimonios de las Sagradas Escrituras, tú apoyas tu postura en opiniones de los filósofos, y en la de Aristóteles continuamente, como pisoteando la de San Pablo. A ese filósofo le concedes en cualquier conversación tanta importancia que das la impresión de defender que sus palabras no son las opiniones de un hombre, sino oráculos de algún dios. ${ }^{58}$

Leopoldo compara a Demócrates con Santo Tomás de Aquino, "quien continuamente se empeña en hacer de Aristóteles un cristiano, apoyando las leyes cristianas en enseñanzas de los peripatéticos, contra la tradición y opinión de los antiguos teólogos". ${ }^{59}$ Demócrates replica que la objeción sería pertinente si se discutieran cuestiones que exceden la razón natural, donde "conviene someter a esclavitud la inteligencia en servicio de Cristo":

En cambio, cuando se trata de las costumbres y se debate sobre las virtudes y sus contrarios, la primera autoridad es la de la Escritura, pero le sigue la de los filósofos; no la de todos, ciertamente, sino la de los más reconocidos, como son los platónicos y todavía más los peripatéticos, que miden el sumo bien con el ejercicio sin trabas de la virtud. ${ }^{60}$

¿Qué entender por "natural”, qué por "naturaleza"?

\section{Derecho natural y esclavitud}

Dado que Sepúlveda comenzó su carrera intelectual traduciendo textos aristotélicos de filosofía natural, no puede sorprender que la cosmovisión jerárquica del Estagirita dejara su poso. El derecho natural, escribe, parte de un único axioma: "el imperio y dominio de la perfección sobre la imperfección, de la fortaleza sobre la debilidad, de

\footnotetext{
Demócrates primero II 5, 6, pp. 116-117.

Demócrates primero II 9, 1, pp. 120-121.

Demócrates primero II 9, 2, p. 121.

Demócrates primero II 11, 1, p. 122.
} 
la virtud excelsa sobre el vicio". ${ }^{61}$ Esta definición, que rebasa el ámbito estrictamente jurídico, se convierte en determinación ontológica que regula y determina la totalidad de lo real y, en consecuencia, ofrece el principio general que se encuentra en la raíz de la construcción política de Sepúlveda: la relación mandato-obediencia, que se extiende a lo largo y ancho de toda la naturaleza. Tal relación es "natural" y fue puesta de manifiesto por Aristóteles, pero ya sabemos que el Estagirita, de acuerdo con Sepúlveda, se limitó a escribir lo que es y quiere la "naturaleza".

En el caso de los seres humanos, esta relación universal y abstracta de mandatoobediencia se articula como dominio, que puede ser político o despótico:

En efecto, a los hombres probos, humanos e inteligentes les conviene el imperio civil, que es propio para personas libres, o el poder regio, que imita al paterno; a los bárbaros y a los que tienen poca discreción y cultura les conviene el dominio heril. ${ }^{62}$

Así pues, por un lado el civile imperium; por otro, el herile imperium. ${ }^{63}$ De este planteamiento se sigue la existencia de tres tipos de hombres: los que por su superioridad han nacido para mandar, los que por su inferioridad deben obedecer y el resto de los humanos que se encuentran entre estas dos clases, "que no destacan por su prudencia y talento pero tampoco están destituidos de él"; tales individuos, "cuyo número es grande, no son ni señores por naturaleza ni esclavos por naturaleza". ${ }^{64}$

La misma diversidad que se da entre los hombres se observa también entre las naciones: las hay "más civilizadas y prudentes" y las hay "salvajes"; el criterio para distinguirlas es la observancia o no observancia de la razón y la ley natural. Las primeras deben mandar y las segundas obedecer, incluso si es necesario a la fuerza, por las armas. ${ }^{65}$ Por eso es fundamental construir el concepto de "pueblos inferiores", o sea, un enemigo en el sentido de Carl Schmitt, justamente lo que Sepúlveda hace en el Demócrates segundo, un texto escrito cuando ya es cronista oficial del emperador Carlos V, cargo para el que es nombrado en el 1536: está familiarizado con los entresijos prácticos del poder imperial, más allá de los planteamientos puramente teóricos.

El "descubrimiento" de América tuvo lugar en una época que se conoce como "Renacimiento", un momento en cuya autocomprensión la Antigüedad juega un papel fundamental. ${ }^{66} \mathrm{Y}$ los renacentistas ven en ella sobre todo una nueva imagen del hombre: solo desde una humanidad ideal -ese "hombre" que con tanto ahínco buscan los "humanistas"- puede investigarse en qué medida los seres humanos concretos y

\footnotetext{
${ }_{61}$ Demócrates segundo I 5, p. 54.

${ }_{62}$ Demócrates segundo II 8, 1, p. 130.

63 Acerca de la monarquía I 2, p. 48.

64 Acerca de la monarquía I 3, p. 49.

${ }_{65}$ A la inspiración aristotélica se une ahora el modelo romano: "Según este derecho los romanos, pueblo sumamente civilizado y destacado por su vigor, sometieron a su poder a las naciones bárbaras". Sepúlveda insiste una vez más en la continuidad entre Roma y España: el mismo derecho que asistió a los romanos asiste a los españoles en su relación con las Indias (“... aquella decisión de vuestros bisabuelos [Isabel y Fernando] de someter a los salvajes bajo su poder"), pues España "es nación notable por su civilización y toda clase de virtudes". Los romanos son modélicos desde una doble perspectiva: por su superioridad natural frente a los bárbaros de su época y porque supieron ejercer tal superioridad con proverbial clemencia y moderación.

${ }_{66}$ Sobre estas cuestiones, Nippel 1991, en particular: "Etnographie und Anthropologie bei Herodot" (11-29) y "Altertum und Neue Welt" (30-55).
} 
empíricos satisfacen o dejan de satisfacer esa humanidad ideal. O como dice Carl Schmitt: únicamente con el ser humano en el sentido de una humanidad absoluta aparece, como la otra cara del mismo concepto, "su específico nuevo enemigo, el Unmensch" ${ }^{67}$ Y dado que contra los enemigos es legítimo emplear la fuerza, el caso americano constituye un aspecto concreto del problema más general señalado más arriba, el del uso de la violencia. Y sin descartar por entero otras razones, tal vez aquí deba situarse el motivo por el que Sepúlveda participó en la polémica sobre el Nuevo Mundo, a saber, para demostrar la utilidad práctica de los estudios clásicos. No debe olvidarse que al mismo tiempo que escribe el Demócrates segundo traduce la Política: traducir, decía más arriba, no es inútil pasatiempo en función de una erudición vacía.

En el Prólogo al Demócrates segundo, Sepúlveda afirma haber escrito "un diálogo al estilo socrático" sobre la justicia o injusticia de "la guerra con que los reyes de España y nuestros compatriotas han sometido y procuran someter a su dominio a aquellos pueblos bárbaros que viven en la región occidental y austral, llamados comúnmente indios"; importa, pues, "en qué justa razón puede fundarse el imperio sobre estas gentes". En líneas generales interesan dos cuestiones: de un lado, la ya aludida de la compatibilidad entre el "pacifismo evangélico", que pide poner "la otra mejilla", y el derecho natural, que permite repeler con violencia las injusticias; de otro, la legitimidad de una política imperial o, más exactamente, la definición de una política imperial justa.

Ahora bien, aunque complejas, las cuestiones sobre las que versa el Demócrates segundo no parecen encontrarse entre aquellas "que exceden la capacidad humana y que el hombre solo puede conocer por revelación divina", precisamente porque se trata de problemas "naturales". Y porque estamos ante problemas "naturales", insisto, es legítimo recurrir a las leyes naturales y los filósofos paganos, en particular Platón y Aristóteles, los "mejores y más sagaces tratadistas de filosofía natural y moral y de todo género de Política", al punto de que sus teorías "han sido recibidas por la posteridad con tan unánime aprobación, que ya no parecen palabras de un solo filósofo, sino sentencias y decisiones comunes a todos los sabios". ${ }^{68}$

Ahora bien, el problema no está en el derecho natural, al que en el fondo todos apelan, sino en su interpretación y en quién puede y debe interpretarlo: los sabios, que lo son entre otras cosas porque conocen y han hecho suyas las reflexiones de Platón y Aristóteles. Y porque, cabría añadir, son capaces de cristianizarlos: "por instinto divino y magisterio de la naturaleza" Sócrates, Platón y Aristóteles eran monoteístas. A la pregunta de Leopoldo -“¿Acaso tú crees que Platón y Aristóteles admitieron la existencia de un solo Dios, cuando a cada paso nos hablan de muchos dioses y a algunos hasta los denominan por sus nombres: Júpiter, Saturno, Marte, Mercurio y así a otros muchos?"-, Demócrates responde que no hay impiedad en usar metafóricamente el plural "dioses". ${ }^{69}$ Por lo demás, dado que el derecho natural también fue promulgado por Dios, Sepúlveda no duda de la salvación de esos filósofos paganos que a sus rectas creencias en Dios unían "una buena conducta conforme a la ley natural". ${ }^{70}$

De acuerdo con la interpretación que Sepúlveda ofrece de estos filósofos paganos convenientemente cristianizados, tres causas justifican la guerra: "repeler la fuerza con

67 Schmitt 1950, 72.

68 Demócrates segundo I 3, p. 48.

69 Demócrates segundo I 13, p. 75.

70 Demócrates segundo I 14, 2, p. 78. Véase la carta a Pedro Serrano del 10 de mayo de 1554 (Epistolario, carta $115,332)$ 
la fuerza cuando no queda otro recurso", "la recuperación del botín injustamente arrebatado", y "la imposición del castigo a quien ha cometido la ofensa", es decir, la venganza de Dios "por intermedio de sus ministros que son en este caso los príncipes y magistrados". ${ }^{71}$ Dado que ninguna de estas causas puede aplicarse a las guerras contra los indios, hay que diseñar una cuarta que, a pesar de no ser "de tanta aplicación ni tan frecuente", es tenida "por muy justa y se funda en el Derecho natural y divino" y que, además, es "la más aplicable a esos bárbaros llamados vulgarmente indios":

... que aquéllos cuya condición natural es tal que deban obedecer a otros, si rehúsan su gobierno y no queda otro recurso, sean dominados por las armas; pues tal guerra es justa según opinión de los más eminentes filósofos. ${ }^{72}$

En este paso recurre Sepúlveda a la teoría aristotélica de la esclavitud natural. El análisis aristotélico de esta cuestión es extraordinariamente sutil y aquí solo puedo esbozarlo en sus líneas más generales. Aristóteles reflexiona sobre la esclavitud en el contexto de su investigación de la administración doméstica. Un esclavo es un instrumento animado; tales instrumentos son necesarios porque los inanimados no se mueven por sí mismos. Por eso debe distinguirse asimismo entre instrumentos para la producción y para la acción: dado que la vida es acción y no producción, los esclavos serán instrumentos para la acción. Este análisis de Política debe completarse con Etica eudemia ${ }^{73}$ donde se lee que las relaciones alma/cuerpo, artesano/ instrumento y amo/esclavo no dan lugar a una comunidad, pues mientras que alma, artesano y señor son una unidad, cuerpo, instrumento y esclavo no son para sí mismos, sino en función, respectivamente del alma, del artesano y del señor. Por otra parte, dado que el "bien" de la verdad poiética tiene que pensarse en relación con la satisfacción de las necesidades del usuario, hay que sostener que la eficacia instrumental no se dice del que usa sino de lo usado, pero no en sí mismo sino en tanto que lo usado es usado en función del que usa (alma, artesano o señor). Si A es en función de B en el sentido de que A no es para sí, sino para B, A es simple y sencillamente una propiedad de B. Se entiende así la definición del esclavo "por naturaleza" como aquel "que no se pertenece a sí mismo, sino a otros a pesar de ser hombre". ${ }^{74}$

71 Demócrates segundo I 4, pp. 51-53. Véase Fernández Santamaría 2007.

72 Demócrates segundo I 5, p. 53. O, por decirlo con las palabras del Del nuevo mundo (I 12, p. 47): filósofos y jurisperitos coinciden en que "a los pueblos bárbaros, es decir, a los que públicamente tienen hábitos e instituciones que chocan con el esquema de la naturaleza, se les puede por Derecho natural, si se negaren, obligar incluso por las armas a obedecer el imperio de hombres más civilizados y sabios, de forma que sean así gobernados por leyes justas emanadas de aquellos y de la naturaleza". Véase el planteamiento general y abstracto del Acerca de la monarquía III, 13-21.

73 Arist. Pol. 1.3; EE 1241 b 15-18.

74 Arist. Pol. 1254a. Aristóteles, pues, analiza la esclavitud en abstracto al hilo de la dialéctica posesión/poseedor, suponiendo que hay individuos que poseen una naturaleza puramente instrumental y, en consecuencia, que es bueno para ellos obedecer y ser mandados. En un segundo momento se interroga por tal supuesto: ¿existen por naturaleza seres humanos que sean una posesión? ¿Existen hombres que se diferencian de los demás hombres del mismo modo que el alma del cuerpo, hombres "cuya función se limita al uso de su cuerpo"? O, dicho de otra manera: ¿existen hombres que "participan de la razón en la medida en que pueden percibirla", pero que ellos mismos no la poseen? Tales hombres serían "esclavos por naturaleza" y para ellos es mejor la esclavitud (Pol. 1254b). Pero el problema y el escándalo no está aquí, sino en la esclavitud "por ley", "entendiendo por ley una suerte de acuerdo en función del cual se afirma que todo aquello que se conquista en guerra pertenece al conquistador" (Pol. 1255a). O sea, hay individuos que son esclavos no por poseer una índole puramente 
A Aristóteles, el más eminente de los más eminentes filósofos, le interesa el problema de los instrumentos para la generación (mujeres) y para la producción (esclavos), le importa qué debe poseer el amo para que haya un oikos, es decir, analiza una cuestión que también importaba a los colonos y conquistadores, que necesitaban y deseaban esclavos para trabajar los campos y en las minas, y mujeres para su placer y para reproducirse. En Sepúlveda el problema se desplaza de nivel: una cuestión de administración doméstica, que tiene que ver con el oikos, se convierte en un problema imperial y, en consecuencia, se sitúa en el nivel del ethnos, sin interés teórico para el Estagirita, porque, a diferencia de la polis en sentido estricto, el ethnos carece de unidad interna y sus miembros no se conocen entre sí; es el caso de Babilonia, "de la que se dice que al tercer día de haber sido tomada, aún no se había enterado de ello una parte de la población". ${ }^{75}$ Sepúlveda, pues, se mueve en un marco conceptual ajeno a Aristóteles y, sin embargo, utiliza instrumentalmente algunas de sus tesis. En efecto, debe mostrar que la condición natural de los indios "es tal que deben obedecer a otros", es decir, que son humanos de un tipo peculiar, como esos "bestiales" a los que se refiere Aristóteles. ${ }^{76}$

Estamos ante esos bárbaros en "sentido propio y estricto" también presentes en Las Casas, ${ }^{77}$ que entiende que a ellos se refiere el Estagirita cuando habla de siervos por naturaleza a los que les conviene ser gobernados por los griegos. ${ }^{78}$ En efecto, diría Sepúlveda, la inhumanidad de los indios, patente en su idolatría, en sus prácticas de antropofagia y en su costumbre de sacrificar seres humanos, es causa justa para declararles la guerra. ${ }^{79}$ No piensa en casos particulares de antropofagia o de sacrificios humanos, sino en prácticas o ritos característicos de toda una nación; de igual modo, la obligación de liberar a los inocentes inmolados en tales ritos no se refiere a casos esporádicos, sino a la actitud nacional, pública u oficial que deben tener los dominadores españoles para con los indios. El momento es importante: como ya había hecho Cicerón, Sepúlveda identifica el ius naturae con el ius gentium primarium de los países civilizados, pues, cuando justifica la guerra contra los indios invocando la "ley natural", apela en realidad a las "normas naturales" del país conquistador. ${ }^{80}$

En Del rito de las nupcias y la dispensa, Sepúlveda recoge la definición de ley natural de Cicerón: "Es ley natural la implantada no por una opinión, sino por una fuerza innata" ${ }^{81}$ Dado que esta fuerza se encuentra, por un lado, "en todo el género de los seres vivos", pero, por otro, "está impresa en cada uno de ellos por especies", se sigue que el derecho natural puede y debe entenderse de dos maneras: 1. esas leyes que los seres humanos tenemos en común con todos los demás seres vivos, según la concepción recogida en la definición de Digesto ${ }^{82} 2$. esas leyes que los

\footnotetext{
instrumental, sino como consecuencia de acciones bélicas: no son esclavos por naturaleza. En tal situación los papeles están mal repartidos, entre amos y esclavos no puede haber ni intereses comunes ni amistad recíproca: los dos fundamentos de la polis.

75 Arist. Pol. $1276 \mathrm{~b} 4$.

76 Arist. EN 1149a 5.

77 “Son crueles, feroces, estólidos, incultos, ajenos a la razón” (Apología cap. 2, 89).

78 Apologética Historia Sumaria cap. 265a, 1581.

79 Demócrates segundo I 12, 2, p. 73. Sorprendentemente, en el Demócrates segundo no se refiere a otro tópico muy generalizado en aquellos debates, la degeneración sexual de los indios, que sí aparece, sin embargo, en Sobre el nuevo mundo (II 8, p. 68).

80 García Pelayo 1941.

81 Del rito de las nupcias y la dispensa II 5, p. 156; Cic. De inv. 2.65.

82 1.1.1.3: "El derecho natural es lo que la naturaleza enseña a todos los animales".
} 
humanos ya no tenemos en común con los demás seres vivos, precisamente porque no nos han sido "inculcadas por los instintos, sino más bien por la razón, mediando la naturaleza como guía y aliada". Ejemplos de leyes naturales en el primer sentido son "el rechazo a los agravios, la procreación y el cuidado de los hijos"; en el segundo, "respetar los acuerdos, no rechazar a los embajadores, cultivar la religión, venerar piadosamente a la patria y a los padres". De estas leyes, las naturales en el segundo sentido de la palabra, "se compone el llamado Derecho de gentes, que toma su nombre del hecho de que de él hacen uso todas las gentes, con tal de que no sean tan bárbaras y salvajes que parezcan haber abandonado por completo la humanidad". De donde se sigue, cabría añadir, que la humanidad se define por hacer uso del derecho de gentes y que el derecho de gentes, a su vez, define a la humanidad. En todo caso, del derecho de gentes "emanaron los Derechos de cada una de las ciudades o reinos correctamente organizados que reciben el nombre de civiles", o sea, el derecho civil: "el que establece para sí cada una de las ciudades" a partir del derecho natural y del de gentes. ${ }^{83}$

Si la humanidad se define por hacer uso del derecho de gentes y si este, a su vez, define a la humanidad, todo dependerá de probar que los indios carecen de razón, pues si así fuera en ellos se rompería esta vinculación entre humanidad y derecho de gentes, pues aunque es obvio que tienen costumbres y leyes (civiles), unas y otras no se derivarían del derecho del gentes, al que los indios, por su irracionalidad, no podrían acceder: los indios, en definitiva, quedan varados por su irracionalidad en el nivel de la ley natural tal y como la define el Digesto y recordaba más arriba. Por tal motivo, les conviene ser clientes. Si en el De regno Sepúlveda propone una "república de optimates", en el De orbe novo recuerda que Colón distribuyó una gran parte de los indios "por clientelas" y pocas líneas más abajo reconoce que los españoles "a quienes les fueron entregados indios en clientela" no cumplieron con el deber legal y moral que les correspondía, "porque no los tratan como a clientes, sino como a esclavos". ${ }^{84}$ Luis Rivera García, en nota a I, 18, explica que "clientes" son súbditos y que a lo largo de todo el texto de Sepúlveda las palabras "clientes" y "clientela" se utilizan, para evitar la aparición de términos no clásicos, como equivalentes de "vasallo" y "vasallaje". ${ }^{85}$ Cierto es que el empleo de neologismos repugna al clasicismo ciceroniano de Sepúlveda, pero también lo es que la utilización de palabras y expresiones latinas puede ayudar a poner de manifiesto la perspectiva desde la que Sepúlveda aprehende el Nuevo Mundo: el modelo clientelar romano se une a cierta nostalgia por el sistema de servidumbre feudal. ${ }^{86}$

Leopoldo, por su parte, considera que "estar sometido por naturaleza al gobierno de otro" es "ser esclavo por naturaleza", afirma que todos los hombres nacieron libres "y que la servidumbre fue introducida por el derecho de gentes y que es algo

83 Quede ahora al margen la cuestión de que la distinción entre ius naturale y ius gentium, desde el punto de vista de la definición de "lo justo" como cualidad del orden social, no está nada clara en Cicerón y, mucho menos, en De inventione; tampoco en De officiis, donde lo justo y lo honesto se aprecian desde la perspectiva de las virtudes personales. El paso al tratamiento del derecho natural como cualidad del orden social es una de las características fundamentales del tomismo (véase, por ejemplo, Graneris 1973). Quede al margen, pues, la cuestión de que Sepúlveda oscila constantemente, tal vez sin ser consciente de ello, entre Aristóteles, Cicerón y Santo Tomás. No puede ni debe sorprender que la lectura sepulvediana de los clásicos esté muy mediatizada por la escolástica.

84 De orbe novo I 26, p. 58.

85 Más detalles en Rivera García 1993, 78.

86 Quirk 1954. 
antinatural" ${ }^{87}$ La objeción permite que Demócrates matice su pensamiento. En primer lugar, distinguiendo dos usos del concepto de servidumbre, el de los jurisconsultos y el de los filósofos:

Para los primeros consiste en cierta condición adventicia que tiene su origen en la fuerza del hombre, en el derecho de gentes y a veces en el derecho civil; los filósofos, en cambio, dan el nombre de servidumbre a la torpeza ingénita y a las costumbres inhumanas y bárbaras. ${ }^{88}$

A continuación, señalando diferentes tipos de dominio, que, aunque poseen disímiles regulaciones jurídicas, se fundan todos ellos en el principio ya mencionado más arriba: "el imperio y dominio de la perfección sobre la imperfección, de la fortaleza sobre la debilidad, de la virtud excelsa sobre el vicio", principio este que se apoya en la recta razón y que, en consecuencia, tiene su fundamento en el derecho natural. ${ }^{89}$ Este principio general también se aplica a las relaciones entre los hombres, esto es, a las relaciones de los varones adultos entre sí:

Los que sobresalen en prudencia y talento, aunque no en robustez física, estos son señores por naturaleza; en cambio, los tardos y torpes de entendimiento, aunque vigorosos físicamente para cumplir los deberes necesarios, son siervos por naturaleza, y añaden los filósofos que para estos no solo es justo, sino también útil, que sirvan a los que son por naturaleza señores. ${ }^{90}$

Tal es, insiste Sepúlveda, el juicio "de los sabios más eminentes", a saber "que es justo y natural el dominio de los prudentes, buenos y humanos sobre sus contrarios", juicio al que se une el modelo romano: "pues no de otro modo justificó el imperio legítimo de los romanos sobre los demás pueblos". ${ }^{11}$

En el capítulo 7 de este primer libro del Demócrates segundo, Leopoldo señala lo obvio, que "en esa guerra contra los indios se cometen grandes estragos y matanzas de personas". Sepúlveda no lo niega, no niega la maldad de algunos, pero esta maldad no invalida "la causa que defienden el príncipe y las personas honradas". ${ }^{92}$ Del hecho de que esta empresa la lleven a cabo varones injustos, inmoderados e inhumanos no se sigue su ilegitimidad, sino la dificultad de cumplirla sin delito ni crimen. $\mathrm{O}$ dicho de otra manera: supuesta la legitimidad y la pertinencia de una política imperial, se discuten los precios a pagar por ella, así como el que esté en las manos adecuadas.

Los indios, por su parte, "en prudencia, ingenio y todo género de virtudes y humanos sentimientos son tan inferiores a los españoles como los niños a los adultos, las mujeres a los varones"; ${ }^{93}$ los indios, en definitiva, son humunculi, porque en ellos apenas si hay vestigios de humanitatis, y esto, en labios de un humanista renacentista como Sepúlveda, no solo quiere decir que carecen de cultura, "sino que ni siquiera usan o conocen las letras ni conservan monumentos de su historia, sino cierta oscura y vaga memoria de algunos hechos consignada en ciertas pinturas, carecen de leyes

\footnotetext{
Demócrates segundo I 5, p. 53.

Demócrates segundo I 5, p. 54.

Demócrates segundo I 5, 4; p. 55.

Demócrates segundo I 5, p. 55.

Demócrates segundo I 8, 4, p. 63.

Demócrates segundo I 7, p. 61

Demócrates segundo I 9, 1, p. 64.
} 
escritas y tienen instituciones y costumbres bárbaras". ${ }^{94}$ En carta a Francisco Argote lo explica con toda claridad: si hay que obligar a los indios "a vivir humanamente y de acuerdo con la ley natural" es que en sus actuales condiciones ni viven humanamente ni de acuerdo con la ley natural. ${ }^{95}$ Aunque Sepúlveda reconoce que los indios "no son osos o monos carentes por completo de razón", 96 insiste en que son bárbaros porque no satisfacen los criterios de humanidad que los humanistas del Renacimiento sí satisfacen y que antaño satisficieron los romanos frente a los pueblos bárbaros. De aquí la legitimidad del Imperio romano, de aquí también la proverbial moderación y clemencia con la que los romanos ejercieron su poder imperial: viri prudentissimi, dice de ellos Sepúlveda al final del libro segundo.

Lo anterior, entre otras cosas, quiere decir que, al menos desde un punto de vista moral, el Nuevo Mundo en modo alguno es nuevo: los problemas morales que plantea pueden tratarse con los conceptos y categorías tradicionales, esto es, con conceptos y categorías antiguos pasados por el filtro de la escolástica. En efecto, para hablar con sentido de "descubrimiento" hay que presuponer que el "descubridor" tiene una posición histórica superior al "descubierto", o sea, que aquel puede conceptualizar a este con su saber y su conciencia. Y esto es exactamente lo que hace Sepúlveda: desde su posición y su saber humanista extrae de la Antigüedad herramientas intelectuales para conceptualizar lo descubierto. O, dicho de otra manera: las reflexiones de Sepúlveda sobre la esclavitud natural aristotélica pueden entenderse como una estrategia intelectual en orden a construir un enemigo funcional para el desarrollo de una política imperial. Por recurrir de nuevo a Schmitt: la dialéctica amigo/enemigo es una descripción fenomenológica que solo tiene sentido si se tiene en cuenta la totalidad de lo político, como hace con toda coherencia y rigor Sepúlveda.

\section{A la sombra del miedo florece la virtud}

En el capítulo 15 del Demócrates segundo, Leopoldo plantea la siguiente objeción:

Si el quebrantamiento de la ley natural es causa justa para la guerra, o me engaño o no habrá nación alguna a la que en justicia no pueda atacársela con las armas por sus pecados y faltas a la ley natural.

Es decir: si los españoles pueden hacer la guerra justa a los indios por los pecados contra la ley natural que estos cometen, lo mismo podrían hacer franceses, italianos o ingleses. Más aún: también los indios pueden declarar la guerra justa a todas estas naciones porque, como dice Leopoldo, "los latrocinios, adulterios, homicidios y otros grandes crímenes con los que vemos que aún los príncipes cristianos corrientemente están contaminados, se cometen contra la ley de la naturaleza". ${ }^{97}$

Sepúlveda vuelve a apoyarse en Aristóteles, ahora en concreto - dice- en el capítulo primero del tercer libro de la Política, donde el Estagirita, investigando diversas

\footnotetext{
Demócrates segundo I 10, p. 65

Epistolario, carta 101, 296.

Demócrates segundo I 10, 3, p. 67.

Demócrates segundo I 15, p. 82.
} 
definiciones de ciudadano, concluye que lo es "quien tiene derecho a participar en la función deliberativa y judicial", 98 lo que Sepúlveda interpreta como sigue: "la conducta de una nación se entiende que está constituida por aquellos actos hechos públicamente por quienes mantienen la dirección política con plena autoridad". Dejando al margen la cuestión de que, al menos desde una perspectiva actual, la interpretación sea algo forzada, interesa ahora la tesis de Sepúlveda. A la pregunta por el sujeto político, responde que la nación y esta, añade, no puede identificarse con los individuos que la componen. También las naciones en abstracto pueden ser "buenas" o "malas", en función de que observen o no la ley natural. Pero el criterio para distinguirlas no es el delito o el pecado en sí, sino la existencia o inexistencia de leyes y principios morales que castiguen o no castiguen el delito y el pecado. ${ }^{99}$ Aunque los españoles como individuos cometan infinidad de pecados y delitos -lo que, como ya recordaba más arriba, Sepúlveda no niega-, España como nación obedece la ley natural porque en ella hay leyes y principios morales que castigan esos delitos. El problema no es la idolatría, la antropofagia o unas costumbres sexuales depravadas, sino la inexistencia entre los indios, al parecer de Sepúlveda, de leyes y criterios morales que castiguen estos pecados. De aquí se sigue la legitimidad del castigo y el deber (humanitario) de imponerlo pues, a fin de cuentas, los malos, sean herejes, paganos o bárbaros, siguen siendo nuestros prójimos. La humanidad es una, si bien sucede que determinadas prácticas sociales y políticas corrompen a determinados pueblos.

En los capítulos 16-18 se plantea el problema de si los paganos deben ser obligados a recibir la fe. De acuerdo con Demócrates, no; pero sí pueden serlo a algo previo: a escuchar el Evangelio. En las siguientes páginas, con mucha habilidad y mucho sofisma, Sepúlveda identifica "escuchar el Evangelio", "ser sometidos a nuestro dominio" y "obedecer la ley natural". Pero dejemos esto a un lado. ¿A la fuerza, con violencia?, pregunta Leopoldo. Demócrates le da la vuelta al argumento: la libertad para predicar el Evangelio ha sido atacada por los indios. Y llegamos así al punto que interesa en estos momentos: los indios han de ser dominados "no solo para que escuchen a los predicadores, sino también para que a la doctrina se unan además las amenazas y se infunda el terror". ${ }^{100}$ Sepúlveda vuelve a apoyarse en Aristóteles: ahora en la teoría del hábito. Sepúlveda presupone, con razón, que los bárbaros han recibido la religión "gracias al terror unido a la doctrina". Ahora bien, los indios rechazan la predicación del Evangelio porque se encuentran "aterrorizados por el temor a sus sacerdotes y príncipes", los cuales, en efecto, aterrorizan a sus súbditos porque entienden que la nueva religión no sirve a sus planes. El terror solo puede combatirse con terror, ${ }^{101}$ porque, como dice Aristóteles, las conductas y las formas de ser ya convertidas en hábitos son muy difíciles de cambiar con palabras y razonamientos. Aristóteles, interpreta Sepúlveda, "asegura que hay necesidad de leyes y violencia para refrenar a los hombres malvados con el miedo al castigo y para engendrar la virtud". Leopoldo comprende de qué va el asunto: Demócrates enseña "que se debe hacer el mal para que suceda el bien". ${ }^{102} \mathrm{O}$ sea, todo depende de

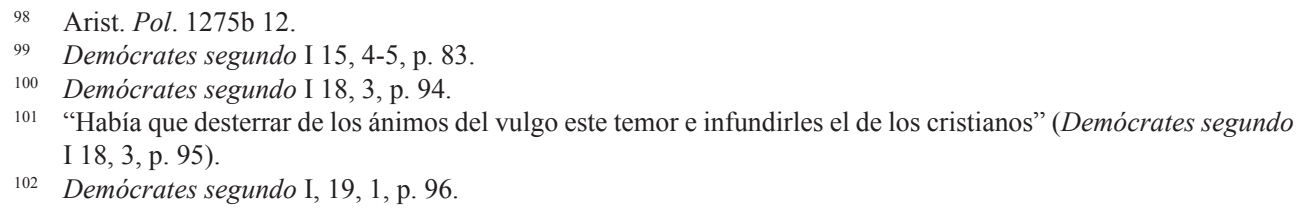


ponderar con equidad - de nuevo Aristóteles- pros y contras: de un lado los males concretos y particulares, de otro lado el bien general de la comunidad, "pues el mal menor, según la doctrina de los filósofos, hace las veces de bien". ${ }^{103}$ Cuando las leyes entran en conflicto, debe dejarse de cumplir "aquella cuya transgresión ocasione menos inconvenientes". ${ }^{104}$

En cierto modo, el argumento de la inferioridad natural de los indios es irrelevante o, más exactamente, aunque desempeña un importante papel retórico a la hora de poner en marcha la argumentación, puede dejarse a un lado. En efecto, pensar que algunos indios han sido condenados a la pérdida de bienes y de libertad por ser siervos por naturaleza sería pueril, pues también entre los pueblos civilizados se encuentran individuos que, aunque libres por derecho civil, son o deberían ser esclavos "según norma de la naturaleza". El problema no son los bienes, sino el uso que se hace de ellos y dado que los indios, cuyos apetitos no obedecen a la razón, los utilizan "para un género de vida condenado por derecho divino", pueden y deben ser privados de ellos. La anulación de los derechos de los indios es condición de posibilidad para la generación de ese Nomos der Erde del que habla Schmitt.

Castilla, en efecto, es la primera monarquía europea que posee partes integrantes de su territorio en otro continente, un continente nuevo, para el que, como señala Pietschmann, "no valían las antiguas justificaciones, ya sean cristianas ya de reconquista, en la lucha contra los países islámicos del norte de África". ${ }^{105}$ Con el descubrimiento aparece, por así decirlo, "de repente" un nuevo espacio que debe ser "dividido/ordenado". De acuerdo con Schmitt, esta "división/ordenación" en realidad "divide/ordena" las relaciones entre las potencias colonizadoras europeas, y no tanto, o solo secundariamente, el territorio ocupado. Sepúlveda lo ve con claridad. Habla Leopoldo:

Sea como enseñas, Demócrates, y sea lícito a los cristianos someter a su dominio naciones bárbaras e impías y apartarlas de sus crímenes y nefandas religiones, pues nada tengo que oponer en contra. Pero si la superioridad en prudencia y virtud y el motivo de la religión da ese derecho a los españoles sobre los indios, ¿por qué no del mismo modo y con igual derecho hubieran podido apropiarse para sí del mismo imperio los franceses o los italianos, en suma, toda nación cristiana que aventaje a estos indios en prudencia, poder y cultura? ${ }^{106}$

\section{Responde Demócrates:}

En verdad parece que la cuestión en principio puede ser materia de duda o disputa, aunque en esta causa el mejor derecho está de parte de la nación que sea más prudente, mejor, más justa y más religiosa; y en todo esto, a decir verdad, muy pocas son las naciones que pueden compararse con España.

La respuesta es pobre, pero la cuestión está planteada: los indios dan igual, el problema está en otro lado. Quiero decir: Sepúlveda no recurre a Aristóteles para

\footnotetext{
103 Demócrates segundo I 6, 1, p. 57.

104 Demócrates segundo II 2, 3, p. 108.

105 Pietschmann 2005, liii.

106 Demócrates segundo I 20, p. 100.
} 
justificar las conductas brutales de los encomenderos, sino para negar a los indios la condición de sujetos políticos. Que de lo segundo se siga con mucha frecuencia lo primero es, por así decirlo, un mal menor: "El mal menor ... puede ser sustituto del bien", escribe Sepúlveda en el Teófilo tras haber establecido, muy aristotélicamente, que el criterio último lo constituye "el hombre prudente", ${ }^{107}$ ese hombre cuyo apetitos obedecen a la razón "sin disgusto"; por eso, como dice Aristóteles, "la prudencia está asociada a la virtud moral y esta, a su vez, con la prudencia". 108

\section{Hacer el mal para alcanzar el bien}

Por detrás de muchas de las cuestiones que han ido apareciendo en las páginas anteriores se encuentra el problema de la legitimidad de hacer el mal para alcanzar el bien, problema este que no deja de ser una concreción del problema teológico y moral de si se comete pecado al hacer a sabiendas un mal menor, un tema muy discutido en la tradición escolástica y en cuyo origen se encuentra la distinción entre actos voluntarios e involuntarios que el Estagirita emprende en Ética Nicomáquea. ${ }^{109}$

Sepúlveda también tradujo la Ética Nicomáquea, traducción lamentablemente perdida, tal vez por las grandes dificultades que tuvo para su impresión. Ante esta circunstancia tuvo que enviar su texto a la Corte para que fuera examinado, tarea esta que llevó a cabo fray Juan de la Fuente, el cual encontró en el texto aristotélico -o sea, en la traducción de Sepúlveda-cuatro "proposiciones heréticas" que expuso en un memorándum dirigido a la Universidad de Alcalá. ${ }^{110}$ Los doctores de esta Universidad solo consideraron problemática la tercera proposición -“Que aquellas acciones que se realizan por miedo a males mayores, son consideradas como involuntarias, lo mismo que si se hiciesen por violencia o ignorancia"-, lo que motivó la respuesta de Sepúlveda:

Los que contradicen aquella sententia de Aristóteles y declaración mía, quae metu maiorum malorum fiunt pro involuntariis habentur, siguen a fray Domingo de Soto por esta razón: por que della se sigue que todo peccado que se haze por euitar otro maior, quando no se pueden euitar entrambos juntos, dexa de ser peccado, lo qual tienen ellos por falso.

Está claro que no puede pecarse para evitar un pecado mayor si el primer pecado es intrínsecamente malo; ahora bien, ¿en qué momento, y bajo qué circunstancias, los pecados intrínsecamente malos dejan de serlo? Por ejemplo: matar es un pecado intrínsecamente malo, pero ¿y hacerlo para evitar una violación, "por evitar el danno de la castidad del cuerpo", por decirlo con las palabras de Sepúlveda? En este caso, argumenta apoyándose en Aristóteles, el pecado intrínsecamente malo deja de serlo, pues se convierte en "involuntario":

\footnotetext{
107 Teófilo X 1-2, p. 224.

108 Demócrates primero II 32, 2, p. 144.

109 Arist. EN 3.1-6.

110 Detalles, referencias y documentos en Losada 1973, 291 y 579-580.
} 
los pecados cometidos "por neccesidad de evitar otro mayor dexan de ser peccado". Los citados doctores, con razón, entendieron que tal proposición mal se aviene con la doctrina paulina y la interpretación que los Santos Padres dieron de la misma: "No hay que hacer el mal para conseguir el bien". Más aún, contradice al mismo Aristóteles, que entiende que hay acciones malas de por sí; ejemplifica con el adulterio, el robo y el homicidio, que siempre son malos en la medida en que no admiten ni el exceso ni el defecto. ${ }^{111}$

Sepúlveda retoma el problema en carta dirigida al doctor Muñoz, rector de la Universidad Complutense de Alcalá, donde recuerda el análisis aristotélico de las acciones voluntarias e involuntarias y señala que la proposición objeto de litigio no es invención suya, sino de Aristóteles "repetida en muchos lugares de la qual yo no soy obligado a dar cuenta y probar que aquella sentençia concierte con la verdad católica". ${ }^{112}$ Él, dice, se ha limitado a "transladar fielmente a Aristoteles y a declarar lo que obscuramente hoviere escrito". Aristóteles, en efecto, al comienzo de Ética Nicomáquea, deja claro que "son involuntarias las cosas que se hacen por fuerza o ignorancia", pero añade: "en cuanto lo que se hace por temor a mayores males ... es dudoso si debe llamarse involuntario o voluntario".113

Es decir, lo que no está claro en el texto de Aristóteles, sí lo estaba, al parecer, en su traducción -traducir, repito, no es tarea inocente- y esta, como sabemos por su correspondencia con Miguel de Arcos, ${ }^{114}$ se corresponde con su pensamiento: es obvio que hay situaciones en las que nos vemos obligados a enfrentarnos ante dos males que no pueden evitarse a la vez, es decir, situaciones en las que debemos elegir entre dos males; en tales circunstancias hay que elegir el menor y tal elección es involuntaria y, en consecuencia, no es pecado.

Queda de este modo, a la manera de Maquiavelo, justificada la funcionalidad del mal en orden al bien y el principio paulino -"no puede hacerse el mal para obtener el bien"- no habla en contra, puesto que el apóstol piensa en bienes voluntarios e inciertos, mientras que Aristóteles -y las demás autoridades citadas por Sepúlveda- se refieren a males forzosos y patentes. O sea, en determinadas circunstancias debe releerse el Nuevo Testamento y a este respecto la Antigüedad -Aristóteles, o determinada traducción de Aristóteles- puede resultar de ayuda. No obstante, en este caso concreto, Sepúlveda, tal vez cansado de polémicas y enfrentamientos, cede:

... y si todo bien mirado a esos señores doctores paresciere que aquella proposition se deue enmendar en mi libro digan la manera como se ha de enmendar y denla scripta en un papel a este criado que lleua esta carta para que el me la trayga porque si yo lo puedo hazer sin caer en mucho inconviniente y sin discrepar de la catholica verdad yo lo corrijire assi.

\footnotetext{
111 “Todas estas cosas y las semejantes a ellas se llaman así por ser malas en sí mismas, no sus excesos y defectos. Por tanto, no es posible acertar nunca con ellas, sino que siempre se yerra. Y no está el bien o el mal, cuando se trata de ellas, por ejemplo, en cometer adulterio con la mujer debida y cuando y como es debido, sino que, en absoluto, el hacer cualquier de estas cosas está mal" (EN 1107a 10-17).

112 Epistolario, carta 133, 388-389.

113 Arist. EN 3.1.

114 Epistolario, cartas 99 y 100. Véase García Pinilla - Solana Pujalte 1966.
} 


\section{Otium cum dignitate}

Los biógrafos de Sepúlveda coinciden en señalar que este -y con mayor frecuencia según iba envejeciendo y, decía, tal vez cansado de enfrentamientos-gustaba pasar cada vez más tiempo en su finca de Sierra Morena. En este contexto vuelve a emerger la figura de Cicerón, porque la idealización del Arpinate no se limita a cuestiones estilísticas e intelectuales, sino que llega a la identificación personal: siendo uno y otro de orígenes humildes, alcanzaron sin embargo destacadas posiciones e importantes patrimonios gracias a su labor intelectual, no enfocada al gabinete, sino abierta al mundo y sus tensiones. Sepúlveda se siente en su finca de Sierra Morena como si fuera Cicerón en Túsculo. En carta dirigida Martín Pérez de Oliván del 1 de octubre de 1551, resuena el motivo del otium cum dignitate:

Me entregaron tu carta, Oliván, llena de cortesía y afecto, en mi finca de Sierra Morena, a donde suelo retirarme para disfrutar del tiempo libre y trabajar, con no menos agrado que lo hacía Cicerón a la suya de Túsculo que inmortalizó en sus doctísimos y elocuentísimos escritos. ${ }^{115}$

En la descripción de esta finca hay ecos virgilianos y reminiscencias de la labor naturalista de Aristóteles; ejemplifico con la que dirigió al franciscano Luis Carvajal el 14 de febrero de 1552, en la que Sepúlveda se embelesa con las abejas:

Me deleita sobremanera contemplar la pericia y el cuidado de su sociedad, a la cual dedican sus tareas compartidas con grandísimo deseo y admirablemente, y los demás grandes milagros que Aristóteles y los demás autores que tratan sobre el campo refieren a este pequeño insecto. Mi finca en Sierra Morena me proporciona este agradabilísimo espectáculo y esta oportunidad de filosofar. ${ }^{116}$

\section{Referencias bibliográficas}

Avalle-Arce, J. B. (1974): Las memorias de Gonzalo Fernández de Córdoba (=North Carolina Studies in the Romance Languages and Literature 155), Chapel Hill.

Brière, Y. de la (1944): El derecho de la guerra justa. Tradición teológica y adaptaciones contemporáneas, México.

Casas, B. de las

(1988): Apología. Obras completas 9, Madrid (edición de Ángel Losada).

(1992): Apologética Historia Sumaria. Obras completas 6, 7 y 8, Madrid (edición de Vidal Abril Castelló, Jesús A. Barreda, Berta Ares Queija y Miguel J. Abril Stoffels) .

Castilla Urbano, F. (2008): "Rasgos maquiavélicos de un pensador antimaquiaveliano: Juan Ginés de Sepúlveda”, [en] J. M. Fonte - P. Álvarez López (eds.), Maquiavelo y España. Maquiavelismo y antimaquiavelismo en la cultura española de los siglos XVI y XVII (=Razón y Sociedad 85), Madrid, 111-134.

Coello de la Rosa, A. (2012): Historia y ficción. La escritura de la Historia general y natural de las Indias de Gonzalo Fernández de Oviedo y Valdés (1478-1557), Valencia.

115 Epistolario, carta 95, 267.

116 Epistolario, carta 96, 272. 
Coroleu, A. (1992): “Il Democrates primus di Juan Ginés de Sepúlveda: una nuova prima condanna contro il Machiavelli", Il Pensiero Politico 2, 263-258.

Gerbi, A. (1978): La naturaleza de las Indias Nuevas. De Cristóbal Colón a Gonzalo Fernández de Oviedo, México.

Fabregat Barrios, S. (2003): "Presencia y función de los mitos clásicos en la Historia General y Natural de las Indias de Gonzalo Fernández de Oviedo y Valdés", Epos 19, 67-88 (https://doi.org/10.5944/epos.19.2003.10397).

Fernández Buey, F. (1995): La barbarie. De ellos y de los nuestros (=Paidós. Biblioteca del presente 4), Barcelona.

Fernández de Oviedo, G. (1959): Historia general y natural de las Indias (=BAE 128-133), Madrid.

Fernández Santamaría, J. A. (2007): Juan Ginés de Sepúlveda: la guerra en el pensamiento político del Renacimiento, Madrid.

Folena, G. (1991): Volgarizzare e tradurre (=Piccola Biblioteca Einaudi), Torino.

Furlan, M. (2002): La retórica de la traducción en el Renacimiento. Elementos para la constitución de una teoría de la traducción renacentista, Tesis doctoral, Universitat de Barcelona, Barcelona.

García Pelayo, M. (1941): "Estudio", [en] Juan Ginés de Sepúlveda. Tratado de las causas justas contra los indios, México, 12-17.

García Pinilla, J. - Solana Pujalte, I. (1966): “Correspondencia inédita entre Juan Ginés de Sepúlveda y Miguel de Arcos”, Helmántica. Revista de filología clásica y hebrea 142143, 261-295.

García Yebra, V. (1979): “Lutero, traductor y teórico de la traducción”, Arbor 102, 323-334.

Garin, E. (1947-1950): "Le traduzione umanistiche di Aristotele nel secolo XV", Atti e memorie dell'Academia Fiorentina di scienze morali "La Colombaria" 16, 55-104.

Ghia, W. (2008): Tra Spagna, Italia e Nuovo Mondo: il pensiero político di Juan Ginés de Sepúlveda, Napoli.

Gil, J. (2007): “Introducción histórica”, [en] Juan Ginés de Sepúlveda, Epistolario. Obras completas 8, Pozoblanco.

Graneris, G. (1973): Contribución tomista a la filosofía del derecho, Buenos Aires.

Gualdo Rosa, L. (1985): "Le traduzione dal greco nella prima metá del '400: alle radici del clasicismo europeo", Latomus 187, 177-194.

Losada, A.

(1970): Fray Bartolomé de Las Casas a la luz de la moderna crítica histórica, Madrid.

(1973): Juan Ginés de Sepúlveda a través de su "Epistolario” y nuevos documentos, Madrid.

MacCormack, S. (2009): On the Wings of Time. Rome, the Incas, Spain, and Peru, Princeton.

Maravall, J. A. (1984): "Maquiavelo y el maquiavelismo en España", [en] Estudios de historia del pensamiento español. Serie tercera. El siglo del Barroco, Madrid, 41-76.

Morrás, $\mathrm{M}$.

(2000a): Manifiestos del humanismo (=Nexos. Península 61), Barcelona.

(2002b): "El debate entre Leonardo Bruni y Alonso de Cartagena: las razones de una polémica", Quaderns. Revista de traducció 7, 33-57.

Muñoz Machado, S. (2012): Sepúlveda, cronista del Emperador, Barcelona.

Nippel, W.(1991): Griechen, Barbaren und “Wilde”. Alte Geschichte und Sozialanthropologie, Frankfurt am Main.

Pagden, A. (1988): La caída del hombre. El indio americano y los orígenes de la etnología comparativa, Madrid. 
Pehlan, J. L. (1974): "El imperio cristiano de Las Casas, el imperio español de Sepúlveda y el imperio milenario de Mendieta", Revista de Occidente 47, 292-310.

Pérez de Tudela, J. (1959): "Vida y escritos de Gonzalo Fernández de Oviedo", [en] Historia natural y general de las Indias, vol. 1, Madrid, vii-clxxv.

Pietschmann, H. (2005): “Introducción histórica”, [en] Juan Ginés de Sepúlveda, Del nuevo mundo. Obras completas 11, Pozoblanco.

Quirk, R. E. (1954): “Some Notes on a Controversial Controversy: Juan Ginés de Sepúlveda and Natural Servitude", Hispanic American Historical Review 34, 357-364 (https://doi. org/10.2307/2508897).

Reynolds, W. A. (1962): "Hernán Cortés y los héroes de la Antigüedad", Revista de filología española 45, 259-290.

Rivero García, J. (1993): El latín del “De Orbe Novo” de Juan Ginés de Sepúlveda (=Editorial Universidad de Sevilla. Filosofía y Letras 159), Sevilla.

Rubio Tovar, J. (1997): “Algunas características de las traducciones medievales”, Revista de Literatura Medieval 9, 197-243.

Rus Rufino, S. (2010): “Estudio histórico. Aristotelismo y antropología en Juan Ginés de Sepúlveda", [en] Juan Ginés de Sepúlveda, Obras completas 15, Pozoblanco.

Sánchez Gázquez, J. J. (2005): Los "De fato et libero arbitrio libri tres” de Juan Ginés de Sepúlveda: Estudio de una obra histórico-filosófica-teológica, Granada.

Schmitt, C. (1950): Der Nomos der Erde im Völkerrecht des Jus Publicum Europaeum, Berlin.

Sepúlveda, J. G. de

(1997): Demócrates segundo. Obras Completas 3, Pozoblanco (edición de A. Coroleu Lletget).

(2001): Del rito de las nupcias y la dispensa. Acerca de la monarquía. Obras completas 6, Pozoblanco (edición de J. M. Rodríguez Peregrina; con "Introducción jurídica” de J. M. Pérez-Prendes Muñoz-Arraco).

(2005): Del nuevo mundo. Obras completas 11, Pozoblanco (edición de L. Rivero García). (2007): Epistolario. Obras completas 8, 9.1 y 9.2, Pozoblanco (edición crítica y traducción de I. J. García Pinilla y J. Solana Pujalte).

(2010): Teófilo. Sobre el destino y el libre albedrio. Obras completas 15, Pozoblanco (introducción filológica, edición crítica, traducción y notas de J. M. Núñez González).

Serés, G. (1997): La traducción en Italia y España durante el siglo XV. La "Ilíada en romance" y su contexto cultural (=Ediciones Universidad de Salamanca. Textos recuperados 16), Salamanca.

Turner, D. (1971): "Los libros del alcaide: la biblioteca de Gonzalo Fernández de Oviedo y Valdés", Revista de Indias 31, 139-198.

Valverde Abril, J. J. (2006): “Teología y humanismo: La correspondencia entre Juan Ginés de Sepúlveda y Melchor Cano", Florentia Iliberritana 17, 291-335.

Vives, J. L. (1947): Obras completas, Madrid (traducción de L. Riber).

Voigt, G. (1893): Die Wiederbelebung des klassischen Altertums, Berlin.

Ynduráin, D. (1994): Humanismo y Renacimiento en España, Madrid. 